\title{
Disparo por arma de fuego de proyectil único del calibre 22 .
}

Gunshot wound by single bullet caliber 22.

A. Rico y cols.

Cuad Med Forense 1999;18:71-72

Se trata de un varón de 70 años de edad que se dispara con una carabina del calibre 22 en el interior de la boca.

El proyectil produce un orificio de entrada en el paladar duro, penetra en la cavidad encefálica a través de la silla turca, atraviesa el parénquima cerebral y la cubierta meníngea y llega hasta el diploe craneal en la región parietal derecha, sin orificio de salida en el cuero cabelludo.

En la imagen se aprecia un orificio en forma de cono truncado con la base hacia su salida. Lo significativo del caso es que el orificio descrito se hallaba cubierto por un fragmento completamente desprendido del diploe craneal que le hacía las veces de "tapadera", presentando en su cara interna (cara interna del diploe) el proyectil impactado y deformado que se observa en el recuadro junto con el fragmento óseo (Fig. I).

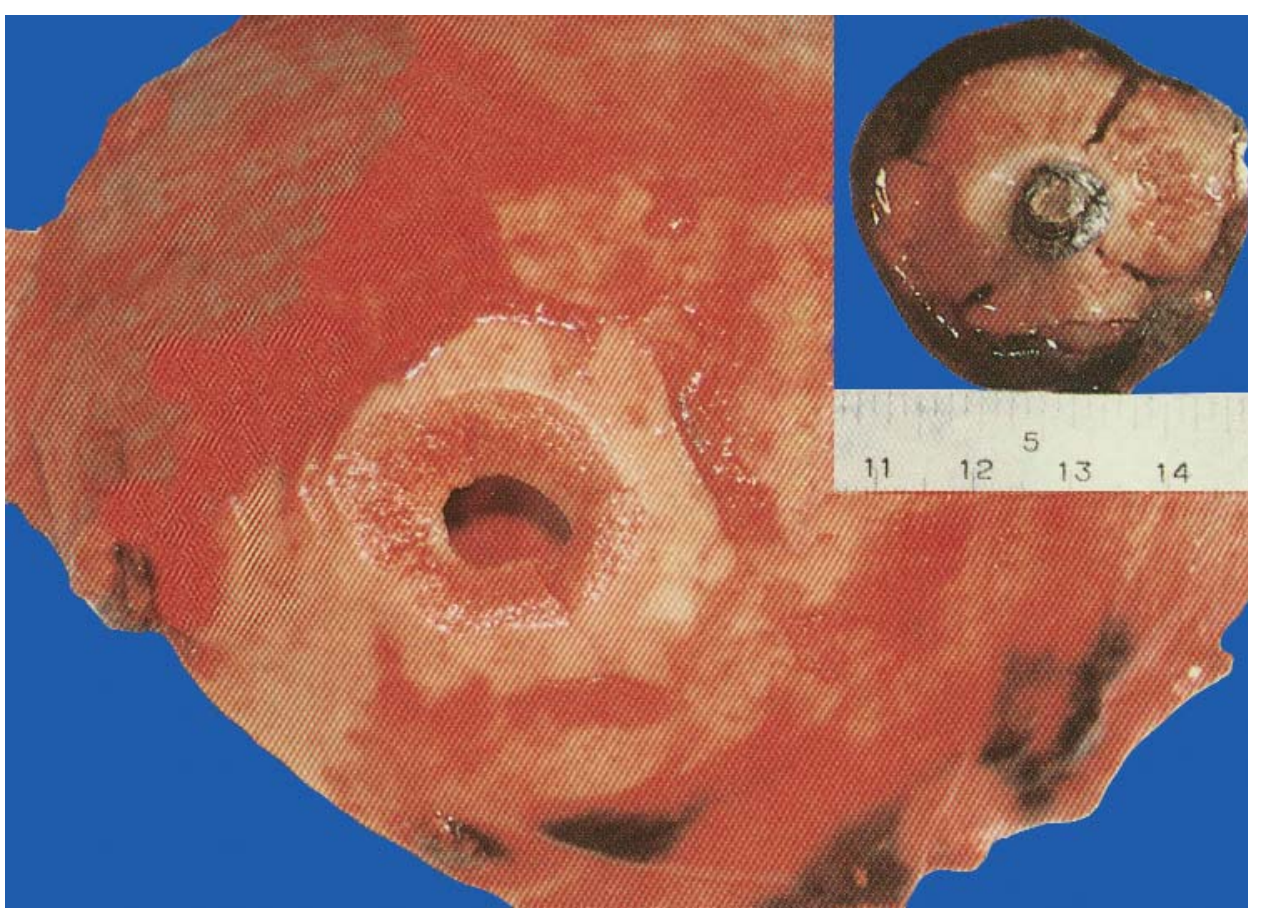

Figura 1.- Orificio de disparo en diploe craneal. En el recuadro se observa el fragmento desprendido con el proyectil impactado. 